\title{
Maybe, maybe not: Probabilistic reasoning in preschool period
}

\section{Belki, belki değil: Okulöncesi dönemde olas1l1ksal ak1l yürütme}

\author{
Ayşegül Ergül ${ }^{1}$,
}

\author{
Article History \\ Received : 14 November 2017 \\ Revised : 13 December 2017 \\ Accepted : 16 January 2018 \\ Online : 17 January 2018 \\ Article Type \\ Original Article
}

\begin{abstract}
Makale Geçmişi
Geliş : :14Kasım 2017

Düzeltme : 13 Aralık 2017

Kabul : 16 Ocak 2018

Çevrimiçi : 17 Ocak 2018
\end{abstract}

Makale Türü

Özgün Makale

\begin{abstract}
Probabilistic reasoning needs careful consideration for the development of the child's ability to interrogate and predict the likelihood based on the findings from the evaluation of various situations or events. Children, hence, will begin to experience metacognitive skills such as considering different causes and effects, decision-making and interpreting. This study aims to explore the probabilistic reasoning skills of preschool children according to the influential variables of gender and age. Typically developing 123 children who are enrolled in the city-centre preschools in Ankara constitute the study group. In the study, five questions were asked in the probability section of the Evaluation Instrument for the Early Mathematical Reasoning Skills developed by Ergül (2014) were posed to identify the probabilistic reasoning skills of the children. Each child was treated individually to gather detailed findings. Children's explanations to the probability questions were evaluated in detail through the use of rubrics. Findings reveal that girls and boys do not differ significantly in their probabilistic reasoning skills; but, in line with the recent literature, these skills improve as they grow up.
\end{abstract}

Keywords: Preschool, probability, probabilistic reasoning, rubric, mathematics

Öz: Olasılıksal akıl yürütme, çocukların farklı durum ya da olaydaki verileri değerlendirme, değerlendirme sonucu elde edilen veriye göre olabilirlik durumunu sorgulama ve tahminlerde bulunma becerilerinin gelişimi için dikkatle ele alınmalıdır. Bu sayede çocuklar farklı nedenleri ve sonuçları görme, karar verme ve yorumlama gibi üst zihinsel becerileri yaşama geçirmeye başlayacaktır. $\mathrm{Bu}$ çalışmanın amacı, okul öncesi dönem çocuklarının olasılıksal akıl yürütme becerilerinin incelenmesidir. Bu becerilere etki edebileceği düşünülen cinsiyet ve yaş değişkenleri de incelenmiştir. Araştırmanın çalışma grubunu, Ankara şehir merkezindeki okul öncesi eğitim kurumlarına devam eden ve normal gelişim gösteren 123 çocuk oluşturmaktadır. Çalışmada çocukların olasılıksal akıl yürütme becerilerini belirlemek için, Ergül (2014) tarafından geliştirilen Erken Matematiksel Akıl Yürütme Becerileri Değerlendirme Aracı'nın olasılık bölümünden beş soru sorulmuştur. Ayrıntılı veriler elde edebilmek için her çocukla bireysel olarak uygulama yapılmıştır. Çocukların olasılık sorularına getirdikleri açıklamalar, rubrikler aracılığıyla ayrıntılı olarak değerlendirilmiştir. Bulgulara göre kız ve erkek çocukların olasılıksal akıl yürütme becerilerinde anlamlı bir fark bulunmazken, son yıllardaki alan yazına paralel olarak bu becerilerin yaşla birlikte gelişme gösterdiği ortaya çıkmıştır.

Anahtar Kelimeler: Okulöncesi, olasılık, olasılıksal akıl yürütme, rubrik, matematik 


\section{INTRODUCTION}

Each and every thing and event that children encounter, provides them who are motivated to explore the life, an opportunity to experience trial-error. Within this process, they progress in their developmental stages while making decisions in line with the environmental stimuli. These stimuli, which may be physical, social, and cognitive, offer many option, probability- to reach a decision. A baby throwing a grape into a bottle can judge whether the grape can be removed or not by evaluating the properties of the bottle. A child observing the behaviour of the parent may act by considering the possibility of getting chocolate. He might prefer a big box that he thinks it could have more toys in it. All these, and many more examples show that children encounter ideas and concepts of probability from the very earliest stages of their life and at any time.

Chance, randomness and probability are statistical concepts that relate to each other and define the logic-mathematical thinking of children. Traditional theories argue that probabilistic thinking develops after the age of seven. However, recent research shows that children can develop basic concepts through mental mechanisms and / or intuitive processes starting from the age of four (Nikiforidou \& Pange, 2009, 2010b).

It is viewed that evaluating the probability lies beneath the trial-and-error, one of the basic exploration and learning methods of the children. In each trial, a different probability situation is enthusiastically considered and applied. Due to the early characteristics of reasoning, children consider the probability situations in terms of their own developmental level.

The relationship between probability and intuition begins to develop from very early years on. It is noteworthy that in many studies with infants and very young children, they are found to make the right decisions in tasks and games based on the concept of probability even though they are quite young (Teglas, Girotto, Gonzalez \& Bonatti, 2007; Bonatti, 2008; Xu \& Garcia, 2008; Denison \& Xu, 2010a).

In Denison, Reed and Xu's (2013) research, 6 months appear to understand something about the predictive relationship between samples and populations; by the end of the first year, infants can compute probabilities in looking-time studies and the output of these computations can guide their action. Infants, who are expected to estimate the numerical ratio, make correct probability predictions despite the increasing number of objects (Denison \& Xu, 2010b). As the babies' perceptions of the object numeracy evolve, they are able to make their preferences 
appropriately even during the period of pre-verbal conversation (Téglás, Ibanez-Lillo, Costa \& Bonatti, 2015).

It is an important feature that babies and children have probabilistic reasoning skills related to different situations or events as stated in the literature. Even though reasoning seems to be limited to more intuitive and simple perceptions in the preschool period, evaluating the data, data-driven questioning of the probability and making estimations provide an important infrastructure for such a skill development. Probability studies should further be conducted in line with children's developmental stages to engage them in metacognitive thinking while children constantly make predictions about different situations and try to improve their knowledge through trial-error. Probabilistic reasoning skills must be practised during the preschool period- a critical time for the acquisition of thinking habits.

Intuitive ideas about chance and probability appear in young children who use qualitative expressions (such as terms "probable" or "unlikely") to express their degrees of belief in the occurrence of random events. These intuitive ideas can be used by a teacher to help children develop a more mature understanding and use probability as a tool to compare likelihood of different events in a world filled with uncertainty (Batanero, Chernoff, Engel, Lee \& Sánchez, 2016).

Surveys indicate that the concept of probability has more of an intuitive nature and may vary for children younger than six years old (Way, 2003; Nikiforidou \& Pange, 2010a). Intuitions may emerge in both formal and informal contexts, but in the case of early years in terms of time intuitive thinking is mainly associated with informal knowledge. Under this perspective, young children are expected to estimate odds and unpredictability and therefore make probability judgments at a certain level, prior to formal learning (Nikiforidou, Pange \& Chadjipadelis, 2013).

Observation of the children's games in the preschool period suggests that they have an untrained vision of the probability concepts and the related situations. Especially, if there is any unfairness between the groups in competitive games, they will immediately express this. In the case of fewer balls, smaller basket or a further distance that can lead to the winning of the other group, unfairness is immediately recognized and they may make comments such as "impossible", "we cannot win, it is not possible" or vice versa "they will definitely win", "they always win as they have more people". Tatsis et al. (2008) have designed games including concepts of probability for 5-year-old-children to have them evaluate the status of fairness. According to findings, most of the children are found to make the right decisions about the fairness of games and that these 
games are important to understanding the concepts of probability. By evaluating the likelihood of the wheels used in children's games, they correctly predicted the group that would finish the cherries in the tree earlier.

The theoretical basis of the child's informal information about the probabilities, the relevant research results and the current probabilistic tasks should be considered when designing a task or a set of probability tasks. The application of the experiment and the use of dice and wheels have a critical position in the development of children's probabilistic thinking. Especially the children in kindergarten have significantly improved their probabilistic thinking ability when given simple and meaningful probabilistic tasks. They can simply discard their subjective interpretations and develop a more basic and quantitative thought. There is evidence that probabilistic reasoning is influenced by the nature and function of the task or problem in question. Tasks that focus on the child's attention to results and on the long-term view of random events help children to develop comprehension skills (Skoumpourdi, Kafoussi \& Tatsis, 2009). According to Van de Walle, Karp and Bay-Williams (2014), it is imperative that a significant preliminary development of realistic concepts of chance is necessary before children are ready to construct formal understandings of the likelihood of a future event. Most likely, this development will take place as children study and discuss a large number of possibilities with their peers. Children's insights into the likelihood of a future event are quite surprising. For example, they were convinced that the next time the dice is thrown it will definitely show three; "Because I am sure about it!" or "Because three is my lucky number!". This first concept is a good starting point to change their misconceptions, concepts of "possible" or "not possible" and then of "impossible", "possible" and "definite" can be emphasised.

The concept of probability can only exist within a framework of random events. Therefore, constructing the mental model of probability runs into significant difficulties when a child is unable to recognise the randomness that characterises a probabilistic situation and instead believes, for example, that the outcome of rolling a dice depends on the ability of the person rolling it (Antonopoulos \& Zacharos, 2013).

How children think probabilistically, their awareness of the causes of their thoughts and their proper explanations form the scope of reasoning. The development and exploitation of existing potentials for children's probabilistic reasoning requires simple but purposeful physical and verbal arrangements in the child's settings and activities. 
This paper considers whether and how preschool children are able to reason about probability. Examination of the probabilistic reasoning skills used by children, it is important to increase the number and quality of the activities. While creating activities that lead children to think about possibility, what are the skills to be developed in the sense of recognizing the existing educational conditions and materials is necessary.

\section{METHOD}

This survey was conducted to examine the probabilistic reasoning skills of children by investigating the effect of gender and age variables on the specified skills. The survey method aims to determine a sample's attitudes, behaviors and opinions numerically within a specified scope (Creswell, 2013).

The research group of the study was 123 children of typical development, aged between 43-78 months who are enrolled in preschools and independent kindergartens of the Ministry of National Education.

Convenience sampling was used for the selection of participants. It is a non-probability sampling technique in which participants are selected due to their accessibility to the researcher. Also it can be used to obtain information relatively quickly and cheaply (Bryman, 2015; Webster, Lewis \& Brown, 2014 )

To conduct the study, permission was received from the Ministry of National Education. The school principals and teachers were offered this permission. Who had previously been granted permission from the parents for such studies, participated to the research in willingly.

Of the children in the working group, $52.8 \%$ were boys and $47.2 \%$ were girls. $16.3 \%$ of the children were in the range of 43-54 months, 31.7\% were in the range of 55-66 months and 52\% were in the range of 67-78 months. Taking into consideration the groups determined by the participating preschools and independent kindergartens these groupings were formed.

\section{Data Collection Tool}

In the research, the probability section of the "Evaluation Instrument for the Early Mathematical Reasoning Skills" developed by Ergül (2014) was used to determine the level of knowledge about the concept of probability of children. The demographic information about the children was gathered from the children's information forms. 
This instrument was prepared with 40 questions in the field of Measurement, Data Analysis and Probability. In order to ensure the reliability of the data obtained from the instrument, the testretest method was applied. Test-retest reliability coefficient is .98. The findings of the item analyses demonstrated that all of the items in the scale were discriminatory. Feedback from the experts was gathered to ensure validity. Kripendorff's alpha was analyzed for the reliability of the rubric. The results showed that (.91) the interrater agreement were very good (Ergül, 2014). A task-based rubric was used in the evaluation of the questions. For each question, the children's comments were evaluated according to the criteria and scored between 0 and 5 .

Rubrics are tools that contain explicit criteria and rules that enable the evaluation of complex performance. Also they provide systematic and rapid recording of opinions, conclusions and evaluations (McAfee \& Leong, 2012). Rubric, in other words rating scale is a form completed by an evaluator to make a judgment of relative standing with regard to a specified variable or list of variables (Cohen \& Swerdlik, 2013).

The literature names two types of rubrics- holistic and analytical. In a holistic rubric, an overall assessment is made while taking into account all of the criteria for the whole performance, in the analytical rubric, each dimension of the task being assessed is scored by the scorer (Brookhart, 2013). In this study, holistic rubric type was preferred because of the age of the children and the aim of identifying the probabilistic reasoning skills.

The holistic assessment rubric is a scoring tool used for the qualitative evaluation of authentic or complex student studies. It also sets the standards for achieving these scores as well as important dimensions of performance (Jonsson \& Svingby, 2007).

Pictures were used in the first and second questions. In the first picture, there is a four-colored circle with slices of different sizes and a black arrow. The most dominant colour in circle slices is yellow, followed by red, blue and green. In the second picture, there are four transparent bags with coloured beads inside. There are four beads in three bags and eight beads in the last. In the other three questions requiring the dice, the same dice was used. There are two number sets of 1,2 and 3 on this dice.

\section{Data Collection Procedure}

The researcher worked with children individually, in a separate area different from their class and with the minimum stimulus. A table and chair suitable for the child's height have been 
provided to make the children physically comfortable. Children have been invited to the room to look at the pictures together. Only volunteer children participated in the study. The questions were asked to all the children in the same order and manner. Responses, comments and observed behaviours were recorded in writing. After all the questions were directed to the child, they were thanked and brought to the child's class. Each application lasted between 25 or 30 minutes. After the researcher worked with all the children who participated in the study at the school, the teachers were informed about the process and the results.

\section{Data Analysis}

The frequency and percentage of correct responses were examined. At the same time, the question averages were evaluated. Comparisons were made with Mann Whitney U and Kruskal Wallis $\mathrm{H}$ tests of non-parametric tests to examine the effects of the variables on the performance of children in probabilistic reasoning skills examined in the study. The evaluation tool used in the research is at the level of the rating scale therefore, non-parametric tests have been taken advantage.

\section{FINDINGS}

The following tables show the results of the analysis of whether the gender and age variables have an effect on the children's scores.

Table 1. Mann Whitney U-test results of probabilistic reasoning skills according to gender

\begin{tabular}{cccccc}
\hline Gender & $\mathbf{n}$ & Mean rank & Sum of ranks & U & p \\
\hline Male & 65 & 63.57 & 4132.00 & 1783.0 & .60 \\
Female & 58 & 60.24 & 3494.00 & \\
\hline
\end{tabular}

As Table 1 displays scores by male and female, it does not indicate any significant difference $(\mathrm{U}=1783.0, \mathrm{p}>.05)$.

Table 2. Kruskal Wallis H-test results of probabilistic reasoning skills according to age

\begin{tabular}{cccccc}
\hline Age (mos) & n & Mean rank & sd & $x^{2}$ & p \\
\hline $43-54$ & 20 & 26.13 & & & \\
$55-66$ & 39 & 50.76 & 2 & 40.76 & .000 \\
$67-78$ & 64 & 80.06 & & & \\
\hline
\end{tabular}

It is seen that the interval of the month leads to a significant difference in the scores gained from the data collection instrument $\left(x^{2}=40.76, \mathrm{p}<.05\right)$. 
After examining the effect of the variables on probabilistic reasoning skills, the percentages of the correct responses to the five questions were organised according to their order of practice in the following five tables.

Table 3. Criteria, score, and percentages of the question "Which colour might the arrow hit when the circle swings fast?"

\begin{tabular}{ccllc}
\hline Response & Score & \multicolumn{1}{c}{ CRITERIA } & \% \\
\hline $\begin{array}{c}\text { Predicted } \\
\text { the }\end{array}$ & $\mathbf{5}$ & S/he provided a a full explanation. Eg. "Most probably yellow". & $\mathbf{2 7 . 6}$ \\
\cline { 2 - 5 } $\begin{array}{c}\text { possibility } \\
\text { correctly }\end{array}$ & $\mathbf{3}$ & $\begin{array}{l}\text { S/he provided an incomplete explanation. Eg. "Possibly it hits when it swings". } \\
\text { fast, I don't know". }\end{array}$ & 1.6 \\
\hline $\begin{array}{c}\text { Predicted } \\
\text { the }\end{array}$ & $\mathbf{2}$ & $\begin{array}{l}\text { S/he knows a little about the concepts/has conceptual confusion/misuses the } \\
\text { concept. Eg. "Red is big". }\end{array}$ & 0.8 \\
\cline { 2 - 5 } $\begin{array}{c}\text { possibility } \\
\text { incorrectly }\end{array}$ & $\mathbf{1}$ & $\begin{array}{l}\text { S/he did not provide any explanation or the explanation was incorrect. Eg. "Red } \\
\text { is in the middle, on the right, because it hit red, I don't know". }\end{array}$ & $\mathbf{5 6 . 9}$ \\
\hline $\begin{array}{c}\text { No } \\
\text { response }\end{array}$ & $\mathbf{0}$ & S/he did not pay any interest at all. & 1.6 \\
\hline
\end{tabular}

When the children are asked the question, the first picture is shown. $27.6 \%$ of the children correctly guessed the possible colour and explained it well. $56.9 \%$ of them wrongly predicted and could not explain or wrongly explained.

Table 4. Criteria, score, and correct response probability percentages of the question "From which bag is it more likely to choose red beads?"

\begin{tabular}{|c|c|c|c|}
\hline Response & Score & CRITERIA & $\%$ \\
\hline \multirow{3}{*}{$\begin{array}{l}\text { Predicted } \\
\text { the } \\
\text { possibility } \\
\text { correctly }\end{array}$} & 5 & S/he provided a full explanation. Eg. "Because there are 2 reds". & $\mathbf{5 0 . 4}$ \\
\hline & 4 & $\begin{array}{l}\text { S/he provided an incomplete explanation. Eg. "All of them have it, reds in here } \\
\text { is possible". }\end{array}$ & 1.6 \\
\hline & 3 & $\begin{array}{l}\text { S/he did not explain at all or provided an unrelated explanation. Eg. "I don't } \\
\text { know, red might jump". }\end{array}$ & 12.2 \\
\hline \multirow{2}{*}{$\begin{array}{l}\text { Predicted } \\
\text { the } \\
\text { possibility } \\
\text { incorrectly }\end{array}$} & 2 & The explanation was incorrect. Eg. "There are many balls here, many beads". & 21.1 \\
\hline & 1 & $\begin{array}{l}\mathrm{S} / \text { he did not explain at all or provided an unrelated explanation. Eg. "I chose this } \\
\text { one, they need to share". }\end{array}$ & 11.4 \\
\hline $\begin{array}{c}\text { No } \\
\text { response }\end{array}$ & $\mathbf{0}$ & $\mathrm{S} / \mathrm{he}$ did not pay any interest at all. & 3.3 \\
\hline
\end{tabular}

The second picture was shown while questioning. $50.4 \%$ of the children correctly predicted the possibility of choosing the red ball and could provide a complete explanation. $21.1 \%$ of them estimated wrongly and explanation was wrong.

The questions that dice were used begin with "Is there a chance of five when I throw it?", which includes the notion of being (existence-non-existence) as it is thought to be easily understood by the children. Before asking this question, the researcher showed the dice to the child. The numbers on it were examined together to ensure that the child knew the numbers on the dice. When the children requested, the dice were given and taken back without asking questions. 
Table 5. Criteria, score, and correct response probability of the question, "Is there a chance to get five when I throw the dice?"

\begin{tabular}{cclc}
\hline Response & Score & \multicolumn{1}{c}{ CRITERIA } & \% \\
\hline $\begin{array}{c}\text { Predicted } \\
\text { the }\end{array}$ & $\mathbf{5}$ & S/he provided a full explanation. Eg. "There is not any 5, it is impossible". & $\mathbf{4 5 . 5}$ \\
\cline { 2 - 5 } $\begin{array}{c}\text { possibility } \\
\text { correctly }\end{array}$ & $\mathbf{3}$ & $\begin{array}{l}\text { S/he provided an incomplete explanation. Eg. "It is likely". } \\
\text { don't know, } 5 \text { makes more". }\end{array}$ & 1.6 \\
\hline $\begin{array}{c}\text { Predicted } \\
\text { the }\end{array}$ & $\mathbf{2}$ & $\begin{array}{l}\text { The explanation was wrong. Eg. "It is sometimes possible, it can, yes it is } \\
\text { possible-chance". }\end{array}$ & $\mathbf{2 9 . 3}$ \\
\cline { 2 - 5 } $\begin{array}{c}\text { possibility } \\
\text { incorrectly }\end{array}$ & $\mathbf{1}$ & S/he did not provide any explanation. Eg. "I don't know". & 12.2 \\
\hline No response & $\mathbf{0}$ & S/he did not pay any interest at all, just looked at the dice. "I don't know." & 1.6 \\
\hline
\end{tabular}

$45.5 \%$ of the children correctly guessed the probability of the number five and could provide a complete explanation. $29.3 \%$ of them wrongly predicted and could not make a correct explanation.

Table 6. Criteria, score, and correct response probability of the question, "Is there a chance to get two when I throw the dice?"

\begin{tabular}{cclc}
\hline Response & Score & \multicolumn{1}{c}{ CRITERIA } & \% \\
\hline $\begin{array}{c}\text { Predicted the } \\
\text { possibility } \\
\text { correctly }\end{array}$ & $\mathbf{5}$ & $\begin{array}{l}\text { S/he provided a full explanation. Eg. "It is possible but not much, there is } \\
\text { maybe 2, possibly". }\end{array}$ & 28.5 \\
\cline { 2 - 5 } & $\mathbf{4}$ & $\begin{array}{l}\text { S/he provided an incomplete explanation. Eg. "2 is probably less likely, } \\
\text { because it must be very little". }\end{array}$ & 20.3 \\
\cline { 2 - 5 } & $\mathbf{3}$ & $\begin{array}{l}\text { S/he did not explain at all or provided an unrelated explanation. Eg. "I don't } \\
\text { know, one is followed by two". }\end{array}$ & $\mathbf{4 0 . 7}$ \\
\hline $\begin{array}{c}\text { Predicted the } \\
\text { possibility } \\
\text { incorrectly }\end{array}$ & $\mathbf{2}$ & The explanation was incorrect. Eg. "It is not possible, it might always be". & $\mathbf{4 . 9}$ \\
\hline No response & $\mathbf{0}$ & S/he did not provide any explanation. Eg. "I don't know". & 4.1 \\
\hline & & &
\end{tabular}

The proportion of children who can tell and explain the probability is $28.5 \% .40 .7 \%$ of the children knew the correct answer but could not give a correct explanation. The proportion of children who wrongly predicted and wrongly explained the probability is $4.9 \%$.

Table 7. Criteria, score, and correct response probability question, "Is there a chance to get numbers smaller than four when I throw the dice?"

\begin{tabular}{cclcc}
\hline Response & Score & \multicolumn{1}{c}{ CRITERIA } & \% \\
\hline $\begin{array}{c}\text { Predicted } \\
\text { the } \\
\begin{array}{c}\text { possibility } \\
\text { correctly }\end{array}\end{array}$ & $\mathbf{5}$ & $\begin{array}{l}\text { S/he provided a full explanation. Eg. "All of them are smaller than 4, it is highly } \\
\text { likely there is 3 2 l". }\end{array}$ & 8.9 \\
\cline { 2 - 5 } & $\mathbf{4}$ & $\begin{array}{l}\text { S/he provided an incomplete explanation. Eg. "Smaller than 4 is possible, } \\
\text { because there are not many 4s". }\end{array}$ & $\begin{array}{l}\text { S/he did not explain at all or provided an unrelated explanation. Eg. "If I throw } \\
\text { it is possible, if you shake it fast there is a chance". }\end{array}$ & $\mathbf{5 0 . 4}$ \\
\hline $\begin{array}{c}\text { Predicted } \\
\text { the } \\
\text { possibility } \\
\text { incorrectly }\end{array}$ & $\mathbf{2}$ & $\begin{array}{l}\text { The explanation was incorrect. Eg. "It is not possible as there is not a 4, it is less } \\
\text { likely because it is bigger than 1, 2, 3 . }\end{array}$ & $\mathbf{2 4 . 4}$ \\
\hline $\begin{array}{c}\text { No } \\
\text { response }\end{array}$ & $\mathbf{0}$ & $\begin{array}{l}\text { S/he did not provide any explanation. Eg. "I don't know, it is less likely because } \\
\text { Sis a big number". }\end{array}$ & 6.5 \\
\hline \hline & Erken Çocukluk Çalşmalar1 Dergisi not pay any interest at all, just looked at the dice. & 4.1 \\
\hline
\end{tabular}


Children were asked to respond by taking into account the numbers on the dice. The percentage of children responding wrongly is $50.4 \%$. $24.4 \%$ of the children wrongly stated the probability and wrongly interpreted the possibility.

\section{CONCLUSION AND DISCUSSION}

In this study, it is aimed to examine the probabilistic reasoning skills of the children in the preschool period. Therefore, 123 children who were attending preschools were asked five probability questions. The answers were evaluated by using rubrics.

There was no significant difference in the mean scores of probabilistic reasoning skills of boys and girls. In addition, there was no gender-related difference in the explanations of the children. Similarly, there are many studies claiming that gender-based differentiation in different math skills did not occur significantly in the pre-school period and begins after 7-8 years of age (Williams, White \& MacDonald, 2016; Merkley, Thompson \& Scerif, 2016; Purpura, Reid, Eiland \& Baroody, 2015)

The effect of age-related development in assessing the probabilistic reasoning is also seen in this study - as in many different types of research (Gonzalez \& Girotto, 2011; Ergül, 2014; Liu $\&$ Chou, 2015). Even the youngest children in the study group were found to have intuitive probability considerations, but the correct response rates of older children were found to be higher. Parallel to this, differences in the nature of the question explanations were observed.

While predicting the probability, younger children have resorted to many subjective judgments such as "I know, I like red". Similarly, they viewed the questions as a problematic situation and tried to find a solution rather than evaluate the possibility. In the case of the older children, although they gave correct answers, their explanations were inadequate. The words such as "I understand these things, I understood in my mind, my father said it, I grew up, I witness it with eyes" are explanations made without using the concepts of probability. Another case observed in the older children is that they have to struggle to explain the questions with other concepts they know. "I understand it from the colours, I know the colours and numbers, and when it is red we stop" are examples of these explanations.

The individualised implementation and argumentation with children especially with the younger provides rich and detailed information as seen in the reasoning skills analysis. In this study, during the individual practice, the children were observed to focus on the correct answer 
and try to answer quickly. Although it was emphasised by the researcher that it was a game, the tendency to focus on the correct answer was often observed.

As mentioned in many research (Webb, Whitlow and Venter, 2017; Brey, 2017; Zacharos, et al, 2016), to analyse and to develop children' reasoning skills, there should be more argumentation, explanation and exploratory talk in child's life.

Probabilistic reasoning skills can be evaluated in more detail by examining the questions separately. The answers given to the questions were extended by the researcher and especially the possibility words were used to help children explain. No feedback was provided to the child's answers and explanations as to whether they are true or false.

In practice, when the responses to the first question are examined "Which colour might the arrow hit when the circle swings fast?", it is seen that $40.6 \%$ of the children correctly estimated the probability. The percentage of children who can give a complete explanation to the right answer is $27.6 \%$. When the rate of correct and incorrect answers is roughly analysed, the total rate of the incorrect answers is identified as more than half. Although rest of the children correctly predicted the likelihood, they could not explain the reasoning. For this question, $57.7 \%$ of the children guessed the answer wrongly. Within this ratio, it is seen that most of them not only predicted the possibility incorrectly but also provided incomplete explanations. The correct answer to this question, as reported in Table 4, is to predict that the chance of yellow colour is higher. The most comprehensive explanation children are expected to give is that colour has the largest area on the circle.

To the second question, $50.4 \%$ of the children accurately predicted the possibility of hitting a red ball and could provide a complete explanation. Predictions and explanations of $21.1 \%$ are wrong. These children who misinterpreted showed the bag with the most balls, and they emphasised this in their explanations. They have interpreted the concept of multiplicity as increasing the probability, ignoring the variable of colour. This problem can lead to different results if asked without the bag with an extra ball that acts as a distractor.

Kafoussi (2004) conducted an empirical study to determine the skills regarding the concept of probability of five-year-old children. Before the training, children's answers were recorded in the experiments including coloured ball or card selection about the predictions of which one would be picked. When asked about their answers, children often stated that they made these choices because "It was their favourite colour" or simply "Because it is possible". However, during the second round of talks on the same experiments after the training, improvements were 
observed in the basic quantitative reasoning of the children. As a result, children used the concepts of "less/fewer" and "more" when describing the probability of collecting balls or cards from the boxes.

Following these two picture questions in the survey, questions were asked about the dice, which could be more challenging in terms of probabilistic reasoning. While estimates in the first two questions lead to relatively more accurate answers, more abstract probabilistic estimates need to be made to the three questions about the dice. Children were asked to run predictions without rolling the dice and to explain their rationale.

$45.5 \%$ of the children correctly guessed the probability of the number five and could provide a complete explanation. $29.3 \%$ of them could not predict and explain correctly, though they were shown the numbers on the dice. The children considered having faced a problem, and they produced a solution like "five comes after four, five dices are needed".

The proportion of children who say the probability of the number two and who are able to explain it with "maybe-sometimes" is $28.5 \%$. $40.7 \%$ of the children provided the correct answer but could not give a proper explanation. These children, who cannot explain well, have followed a disconnected and partly problem-solving approach, such as "I might throw them in the air, keep two upside, the least we get is two". As a result of intuitive thinking, $20.3 \%$ of the children explained the correct answer incompletely. To exemplify, they utter statements like "It is sometimes possible, because every time I throw, it is different as there are a lot of numbers". The proportion of children who wrongly predicted and wrongly explained the probability is $4.9 \%$.

The last question was "Is there a chance to get numbers smaller than four when I throw the dice?". The proportion of children who answered correctly, but could not explain was $50.4 \%$. $8.9 \%$ of the children answered correctly and were able to make the expected full explanation. The percentage of children who answered incorrectly to this question and whose explanation is wrong is $24.4 \%$. A problem encountered in the comments made for this question during implementation is because some children have not acquired the concept of "smaller than four". After the implementation is over, the children giving the answers such as "There are no numbers here smaller than four, here we have only one-two- three", were asked the numbers smaller than four". These children were struggling to count consecutive big or small numbers while they did not have any problems with counting starting from one. As can be seen, children who cannot acquire the number conservation might have problems in probabilistic reasoning situations. 
When these three questions asked by using dice are evaluated together, it is thought that the concepts of probability such as "never-ever, maybe-sometimes and always" do not take much place in the children's life. It has been observed that children who tend to focus on the correct answer avoid using such ambiguous expressions.

During the preschool period, the use of dice often takes place in games. However, as can be understood from the limited number studies on probability, its use is in the form of assessing more numerical knowledge (Park, 2013; Rohmah \& Waluyo, 2014), queuing in games, advancing by the rolled number, adding (Moomaw \& Dorsey, 2013; , 2016) or selecting cards (Cho, Choi \& Lee, 2015) according to many different conventions on the dice (colors, animals, shapes, etc.). Regardless of the form of use in games, dice are of interest and are used with enthusiasm by children (Kotsopoulos \& Lee, 2013). In this study, too, the children approached dice with interest and talked about the games they usually play with their parents with dice.

Using boxes or bags where there are coloured objects and dice, wheels that may contain different concepts in games will provide significant opportunities for the development of probability concepts. Children should be encouraged to play with these materials individually or as a group and dialogues in this process should be observed. In a study by Gürbüz, Erdem and Uluat (2014), the positive effect of the game-based approach for the fourth-year primary school students, the level at which the probability issue was officially addressed, was put forward. In their study, it is proposed to use computer games related to probability in addition to games performed in class. Games for all ages are important and make a difference.

In daily life, parents should also be provided with the necessary guidance to have their children meet the concepts of probability through various competitions and suitable table games. Families want to learn about the possibilities of transferring information while they are having quality time with their children. With the help of educational and entertaining home games, the knowledge that children have gained at school will be supported and the family will be an effective part of this developing effort. In families where children play games that allow the development of various concepts and skills, significant progress has been made in terms of parents (Skwarchuk \& LeFever, 2015; Niklas, Cohrssen \& Tayler, 2016; Streit-Lehmann \& Peter-Koop, 2016) and siblings (How et al., 2015).

In other activities or situations within the classroom, the teacher should use the concepts of probability and the children should be encouraged to adopt this approach. Opportunities should be created for children to "think" about the possibilities in games and other activities. For example, to draw the probabilities in the learning centre participation, to discuss the possibilities 
of weather forecasts and to record forecasts, to discuss situations and events that may or may not happen in various environments we live in (such as summer snow, the speech of bees).

Teachers need guidance on getting such activities and concepts into the curriculum and implementing them. According to Shiakalli, Zacharos \& Lavidas (2017), firstly it is important to identify and comprehend the pre-school teachers' beliefs about probability. Scientific background and required professional abilities related to probability concepts should be developed both pre and in service programs. Efforts should be focused on extracting mathematical content from everyday practices which appear in a pre-school classroom as well as the inclusion of mathematical activities within a meaningful context in order to facilitate effective teaching.

In the study by Nikiforidou and Pange (2009), children evaluated new information given in probability tasks (probability of finding toy animals depending on the number of boxes) and responded differently in each condition depending on the nature and amount of information given. These findings suggest that probabilistic tasks should be designed based on the cognitive capacities of children and their probabilistic conception.

Grotzer, Solis, Tutwiler and Cuzzolino (2017), found that most of the students held a generally deterministic stance despite their ages in their study group. However, repeated opportunities to engage with probabilistic causal tasks enabled some students to realize the probabilistic causal schema. Their results show that probabilistic causal reasoning is not beyond their developmental reach even as kindergartners.

The fact that the underlying cause of the right or wrong answer is perceived and explained by the children and that the reasoning levels of the children can be evaluated more meaningfully with these explanations are realised by the time spent with the children individually. It is believed that more emphasis should be given to the individual evaluation method, especially if the studies planned in the preschool period aims deeper than the "yes-no" answers.

In addition, rubrics preferred for evaluation of children's explanations in terms of probabilistic reasoning help determine both the current developmental levels of the children and the necessary educational steps to be taken for improvement. It is important that the educators who will work with children should be aware of the rubric usage and preparation so that they can plan in detail both the level of skill they want to examine and the training activities they will be doing. Thus, development-based practices emerging directly from the child's needs can be achieved. 
Current research provides a summary of the probabilistic reasoning of children. Longitudinal studies based on observations are recommended to examine the use of cases of probability concepts in everyday life.

\section{REFERENCES}

Antonopoulos, K. \& Zacharos, K. (2013). Probability constructs in preschool education and how they are taught. Teachers and Teaching, 19(5), 575-589.

Batanero, C., Chernoff, E. J., Engel, J., Lee, H. S. \& Sánchez, E. (2016). Research on teaching and learning probability. In Research on teaching and learning probability, ICME-13 Topical Surveys. (pp. 1-33). Springer International Publishing.

Bonatti, L. (2008). At the origin of rationality: how intuitions of probabilities shape predictions about the future. Paper presented at the 16th International Conference on Infant Studies, Vancouver, Canada.

Brey, A. (2017). The effect of ' 6 Bricks' guided play on grade two learners' visual perception and reasoning abilities. Doctoral dissertation, Nelson Mandela Metropolitan University.

Brookhart, S. M. (2013). How to create and use rubrics for formative assessment and grading. USA. ISBN 978-1-4166-1507-1.

Bryman, A. (2015). Social research methods. Oxford University press. https://books.google.com.tr/books?hl=tr\&lr=\&id=N2zQCgAAQBAJ\&oi=fnd\&pg=PP $1 \& \mathrm{dq}=$ convenience + sampling + method $+\mathrm{in}+$ education + researches\&ots $=\mathrm{dnQvIUPaqi} \&$

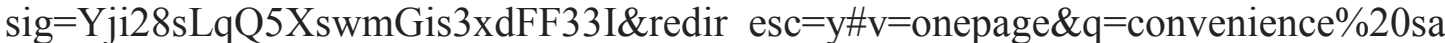
mpling\%20method\%20in\%20education\%20researches\&f=false

Cho, Y. R., Choi, J. \& Lee, Y. (2015). The possibility of play education for improving computational thinking of preschoolers. In EdMedia: World Conference on Educational Media and Technology, Vol. 2015, No. 1, 1160-1163.

Cohen, R. J. \& Swerdlik, M. E. (2013). Psychological testing and assessment: An introduction to tests and measurement. Translation from the 7th edition. Translation editor: E. Tavşanc1l. Nobel Publishing, Ankara.

Creswell, J. W. (2013). Research design: Qualitative, quantitative, and mixed methods approaches. Translation editor: S. Beşir Demir. Eğiten Kitap Publishing, Ankara.

Denison, S. \& Xu, F. (2010a). Integrating Physical Constraints in Statistical Inference by 11 Month- Old Infants. Cognitive Science, 34(5), 885-908.

Denison, S. \& Xu, F. (2010b). Twelve- to 14- month- old infants can predict single- event probability with large set sizes. Developmental Science, 13(5), 798-803.

Denison, S., Reed, C. \& Xu, F. (2013). The emergence of probabilistic reasoning in very young infants: Evidence from 4.5-and 6-month-olds. Developmental psychology, 49(2), 243. 
Ergül, A. (2014). Erken Matematiksel Akıl Yürütme Becerileri Değerlendirme Arac1 Geliştirilmesi. Yayımlanmamış doktora tezi, Ankara: Hacettepe Üniversitesi Sağlık Bilimleri Enstitüsü.

Gonzalez, M. \& Girotto, V. (2011). Combinatorics and probability: Six-to ten-year-olds reliably predict whether a relation will occur. Cognition, 120(3), 372-379.

Gürbüz, R., Erdem, E. \& Uluat, B. (2014). Reflections from the process of game-based teaching of probability. Croatian Journal of Education, 16(3), 109-131.

Grotzer, T. A., Solis, S. L., Tutwiler, M. S. \& Cuzzolino, M. P. (2017). A study of students' reasoning about probabilistic causality: Implications for understanding complex systems and for instructional design. Instructional Science. 45(1), 25-52.

Howe, N., Adrien, E., Della Porta, S., Peccia, S., Recchia, H., Osana, H. P. \& Ross, H. (2015). 'Infinity Means it Goes on Forever': Siblings' Informal Teaching of Mathematics. Infant and Child Development. Volume 25, Issue 2 $137-157$.

Jonsson, A. \& Svingby, G. (2007). The use of scoring rubrics: Reliability, validity and educational consequences. Educational Research Review, 2(2), 130-144

Kafoussi, S. (2004). Can kindergarten children be successfully involved in probabilistic tasks? Statistics Education Research Journal, 3 (1), 29-39.

Kotsopoulos, D. \& Lee, J. (2013). What are the development enhancing features of mathematical play. An Leanbh Óg: The OMEP Ireland Journal of Early Childhood Studies, 7, 47-68.

Liu, I. M. \& Chou, T. H. (2015). A probabilistic approach to conditional reasoning development. Journal of Cognition and Development, 16(3), 522-540.

McAfee, O. D. \& Leong, D. J. (2012). Assessing and guiding young children's development and learning. Translation from the fifth edition. Translation editor: B. Ekinci Palut. Nobel Publishing, Ankara.

Merkley, R., Thompson, J. \& Scerif, G. (2016). Of huge mice and tiny elephants: Exploring the relationship between inhibitory processes and preschool math skills. Frontiers in psychology, 6, 1903-1924.

Moomaw, S. \& Dorsey, A. G. (2013). The use of numeric and non-numeric symbols by preschool children in early addition. Journal of Research in Childhood Education, 27(3), 319-329.

Nikiforidou, Z. \& Pange, J. (2009). Does The Nature And Amount of Posterior Information Affect Preschoolers' Inferences? In Proceedings of CERME 6, 388-393.

Nikiforidou, Z. \& Pange, J. (2010a). "Shoes and Squares": A Computer-Based Probabilistic Game For Preschoolers. Procedia, Social and Behavioral Sciences, 2 (2), 3150-3154.

Nikiforidou, Z. \& Pange, J. (2010b). The Notions Of Chance and Probabilities In Preschoolers. Early Childhood Education Journal, 38 (4), 305-311.

Nikiforidou, Z., Pange, J. \& Chadjipadelis, T. (2013). Intuitive and Informal Knowledge in Preschoolers' Development of Probabilistic Thinking. International Journal of Early Childhood, 45(3), 347-357. 
Niklas, F., Cohrssen, C. \& Tayler, C. (2016). Improving preschoolers' numerical abilities by enhancing the home numeracy environment. Early Education and Development, 27(3), $372-383$.

Park, Y. J. (2013). The Relative Effectiveness of Teacher-made Games for Preschoolers' Understanding Number Concepts. Asia-Pacific Journal of Research in Early Childhood Education, 7(1), 93-119.

Purpura, D. J., Reid, E. E., Eiland, M. D. \& Baroody, A. J. (2015). Using a brief preschool early numeracy skills screener to identify young children with mathematics difficulties. School Psychology Review, 44(1), 41-59.

Rohmah, N. \& Waluyo, E. (2014). Arithmetic Dice Media as Counting Concept Introduction for Early Childhood. Indonesian Journal of Early Childhood Education Studies, 3(2), 127-133.

Shiakalli, M. A., Zacharos, K. \& Lavidas, K. (2017). Preparing pre-school teachers for teaching probability. Review of Science, Mathematics and ICT Education, 11(2), 93-117.

Skoumpourdi,C., Kafoussi, S. \& Tatsis, K. (2009). Designing Probabilistic Tasks For Kindergartners. Journal Of Early Childhood Research, 7 (2) 153-172.

Skwarchuk, S. L. \& LeFevre, J. A. (2015). The Role of the home environment in children's early numeracy development: A Canadian Perspective. In Mathematics and Transition to School, 103-117.

Streit-Lehmann, J. \& Peter-Koop, A. (2016). Investigating the Potential of the Home Learning Environment for Early Mathematics Learning: First Results of an Intervention Study with Kindergarten Children. In Mathematics Education in the Early Years, 99-114.

Tatsis, K., Kafoussi, S. \& Skoumpourdi, C. (2008). Kindergarten children discussing the fairness of probabilistic games: The creation of a primary discursive community. Early Chilhood Education Journal, 36, 221-226.

Teglas, E., Girotto, V., Gonzalez, M. \& Bonatti, L. (2007). Intuitions of probabilities shape expectations about the future at 12 months and beyond. Proceedings of the National Academy of Sciences of the United States of America, 104, 19156-19159.

Téglás, E., Ibanez- Lillo, A., Costa, A. \& Bonatti, L. L. (2015). Numerical representations and intuitions of probabilities at 12 months. Developmental Science, 18(2), 183-193.

Xu, F. \& Garcia, V. (2008). Intuitive statistics by 8-month-old infants. Proceedings of the National Academy of Sciences of the United States of America, 105, 5012-5015.

Van de Walle, J. A., Karp, K. S. \& Bay-Williams, J. M. (2014). Elementary and middle school mathematics: Teaching developmentally. 7th edition. Translation editor: Prof. Dr. Soner Durmuş. Pearson Nobel Publishing, Ankara.

Way, J. (2003). The development of young children's notions of probability. In Proceedings of CERME3. Italy.

Webb, P., Whitlow, J. W., \& Venter, D. (2017). From Exploratory Talk to Abstract Reasoning: a Case for Far Transfer?. Educational Psychology Review, 29(3), 565-581.

Webster, S., Lewis, J. \& Brown, A. (2014) . Ethical Considerations in Qalitative Research. Ritchie, J., Lewis, J., Nicholls, C. M., \& Ormston, R. (Eds.). Qualitative research practice: A guide for social science students and researchers. Second edition, Sage. 
Williams, K. E., White, S. L. \& MacDonald, A. (2016). Early mathematics achievement of boys and girls: Do differences in early self-regulation pathways explain later achievement?. Learning and Individual Differences, 51, 199-209.

Zacharos, K., Pournantzi, V., Moutsios-Rentzos, A. \& Shiakalli, M. A. (2016). Forms of argument used by pre-school children. Educational Journal of the University of Patras UNESCO Chair. 3(2),167-178.

https://books.google.com.tr/books?hl=tr\&lr=\&id=EQSIAwAAQBAJ\&oi=fnd\&pg=PP1\&dq= convenience + sampling + method + in + education + researches\&ots $=1 Z X Q 1$ Zy1P\&sig $=\mathrm{Sr}$ EgOHQOB0NPyRiatkWiY6E_VHg\&redir_esc $=\mathrm{y} \# \mathrm{v}=$ onepage\&q\&f=false 